\title{
Microbial Air Quality in Municipal Buses Before and After Disinfection of their Air-Conditioning Systems
}

\author{
Małgorzata Gołofit-Szymczak ${ }^{1 *}$, Agata Stobnicka-Kupiec ', Rafał L. Górny', \\ Marcin Cyprowski', Anna Ławniczek-Wałczyk' \\ 1 Department of Chemical, Aerosol and Biological Hazards, Central Institute for Labour Protection - National \\ Research Institute, Czerniakowska 16 Str., 00-701 Warsaw, Poland \\ * Corresponding author's e-mail: magol@ciop.pl
}

\begin{abstract}
To ensure the proper quality of the air and simultaneously improve the comfort of professional drivers or travellers, the cars are fit with air-conditioning (AC) systems. The AC installations, however, quite often create suitable conditions for the development of microbiological agents and become an active emission source of harmful bioaerosols. This study was carried out in 6 municipal buses in large city located in central Poland. In studied vehicles, ozonisation or manual application of chemical disinfectant in a spray form were used for disinfection of AC bus systems. The concentrations of bacteria and fungi in the air collected in buses before the service of their AC installations were $4.3 \times 10^{2} \mathrm{CFU} / \mathrm{m}^{3}$ and $2.4 \times 10^{2} \mathrm{CFU} / \mathrm{m}^{3}$, respectively. After AC service using both tested disinfection methods, the decrease in microbial concentrations in the air of municipal buses was observed. The highest effectiveness of AC cleaning was noted when the chemical disinfectant in a spray form was used. This study revealed that to eliminate microbiological contamination and, by that, decrease the exposure of both drivers and passengers to harmful microbial contaminants, the chemical disinfection of bus AC system should be performed at regular basis.
\end{abstract}

Keywords: buses, air-conditioning system, bioaerosol, bacteria, fungi

\section{INTRODUCTION}

In Europe, the most widespread mode of transportation is road transport. Buses are an important means of collective public transport used by large numbers of people [19]. In Poland, the municipal transportation network is used annually by approximately 4 million passengers. In order to improve the comfort of professional bus drivers and passengers, buses are equipped with airconditioning (AC) systems. The improper maintenance of AC installations promotes the multiplication of microorganisms which contaminate the air in vehicles and become their active emission source $[11,14]$. The subsequent exposure of drivers and passengers to microbiological agents may lead to numerous adverse health outcomes, such as irritations, allergic reactions or even infectious diseases and toxic responses [18].
The main purpose of research was to evaluate the level of bacterial and fungal contamination of the air in municipal bases before and after servicing of their AC systems.

\section{METHODS}

The study was performed in the summer in large city (population of over 500,000) located in central Poland. The study involved 6 randomly selected air-conditioned buses. The vehicles were divided into two groups (Table 1). The first group (A1-A4) included buses, which were a part of the inner city transportation fleet (i.e. the public urban transportation network buses) and in which a chemical agent containing propan-2-ol (isopropyl alcohol) was used for regular disinfection of AC systems. The second group (A5-A6) consisted of 
vehicles, which served as 'tourist buses' (cruising within city limits) and in which ozone was used as AC disinfectant. The examined vehicles were manufactured between 2004- and 2014 and their mileage ranged from 310,000 to $576,000 \mathrm{~km}$. In all studied buses, the internal temperature of operated AC system was set at $23^{\circ} \mathrm{C}$.

The air samples were collected before and after disinfection of AC systems in studied buses using a 6-stage Andersen impactor (model WES-710, Westech Instrument, Great Britain). The flow rate and sampling time were $28,3 \mathrm{~L} / \mathrm{min}$ and $5 \mathrm{~min}$, respectively. During the tests, the impactor was placed within the zone of about $0.5 \mathrm{~m}$ from vent/supply air outlets located next to the bus steering wheel and at the height of $1 \mathrm{~m}$ above the car's floor to simulate aspiration from the human breathing zone. Standard Petri dishes filled with blood trypticase soy agar (TSA, 51044, bioMérieux, Marcy l'Etoile, France) and malt extract agar (MEA, Oxoid Ltd., Basingstoke, Great Britain) were used for bacterial and fungal sampling, respectively. All isolated microorganisms were quantitatively analysed using microscopic and biochemical methods [5]. The research results were statistically analysed using Statistica v. 7.1. (StatSoft, Inc., USA). The p values below 0.05 were treated as statistically significant.

\section{RESULTS AND DISCUSSION}

\section{Quantitative analysis of bacterial and fungal biota in air samples}

The microbial aerosol concentrations in studied buses measured before and after the air-conditioning system servicing as well as in outdoor (atmospheric) air are presented in Table 1. The scientific literature review revealed that bioaerosol concentrations in municipal buses generally range between $10^{2}$ - to $10^{4} \mathrm{CFU} / \mathrm{m}^{3}[7,9,10,12]$. The airborne bacterial and fungal concentrations recorded in bus cabins evaluated in this study before the AC system service were within the above range reaching $4.3 \times 10^{2} \mathrm{CFU} / \mathrm{m}^{3}$ and $2.4 \times 10^{2} \mathrm{CFU} / \mathrm{m}^{3}$, respectively. Moreover, the comparison of bacterial aerosol concentrations in the studied buses before disinfection of their AC systems did not show statistically significant differences between the vehicles $(p>0.05)$. However, in case of fungal aerosol concentrations, their statistically higher levels were noted in buses A1-A4. The observed correlations confirm the data found in the scientific literature concerning the microbial emission sources. Major outdoor sources responsible for environmental fungal aerosol release include plants, soil, natural water reservoirs, landfill sites and liquid waste disposal facilities. The penetration of indoor spaces by atmospheric air is the main process (except situations, in which active microbial emission sources are present indoors) responsible for their contamination with fungal conidia. As it was mentioned above, the buses A1-A4 were a part of the public urban transportation network operating solely within the city limits. As such, during a single pass on a specified route, they pull over at a bus stop and open doors (on average) every $490 \mathrm{~m}$ on regular lines and every $820 \mathrm{~m}$ on express ones allowing spontaneous indoor-outdoor air exchange. In turn, the vehicles A5 and A6 were 'tourist buses', in which doors are usually opened at the start and at the end of the trip and, rather occasionally, at bus stops along the way. Hence, the infiltration of the outdoor air and, connected with that, possible contamination of the bus indoor spaces is considerably limited.

Bioaerosol concentrations measured before the AC system service were significantly higher than those observed after cleaning of the AC installation $(p<0.001)$. The use of a chemical disinfectant resulted on average in $67 \%$ reduction

Table 1. Concentration of microorganisms (mean values \pm standard deviations) in the air of municipal buses before and after service of their air-conditioning (AC) systems and in outdoor (atmospheric) air

\begin{tabular}{|c|c|c|c|c|}
\hline \multirow{2}{*}{ Sample } & \multicolumn{2}{|c|}{ Average bacterial concentration [CFU/m ${ }^{3}$ ] } & \multicolumn{2}{c|}{ Average fungal concentration [CFU $\left./ \mathrm{m}^{3}\right]$} \\
\cline { 2 - 5 } & Before AC service & After AC service & Before AC service & After AC service \\
\hline Bus A1 & $280 \pm 169,7$ & $70 \pm 14,1$ & $290 \pm 70,7$ & $80 \pm 0$ \\
\hline Bus A2 & $440 \pm 84,8$ & $100 \pm 56,5$ & $360 \pm 0$ & $170 \pm 14,1$ \\
\hline Bus A3 & $490 \pm 42,4$ & $70 \pm 14,1$ & $300 \pm 28,3$ & $140 \pm 14,1$ \\
\hline Bus A4 & $290 \pm 70,7$ & $150 \pm 42,4$ & $230 \pm 70,7$ & $50 \pm 14,1$ \\
\hline Bus A5 & $520 \pm 84,8$ & $140 \pm 0$ & $180 \pm 28,3$ & $140 \pm 28,3$ \\
\hline Bus A6 & $460 \pm 84,8$ & $190 \pm 14,1$ & $180 \pm 0$ & $130 \pm 14,1$ \\
\hline Outdoor air & \multicolumn{2}{|c|}{$300 \pm 141,4$} & \\
\hline
\end{tabular}


of both bacterial and fungal aerosol concentrations, while in the case of ozone-based AC cleaning the reductions in concentrations were at the levels of $66 \%$ and $25 \%$ for airborne bacteria and fungi, respectively. These findings confirmed that both methods of the AC system disinfection efficiently decreased the airborne concentrations of microbial propagules in municipal buses; however, the use of chemical disinfectant containing propan-2-ol was more effective.

A comparison of microbial aerosol concentrations measured outdoors and inside the studied buses before and after the AC system service revealed that the atmospheric fungal levels were considerable higher than those observed inside the vehicles ( $p<0.001$ in both cases). In case of bacterial aerosol, its concentrations measured inside the studied buses before the AC service were considerable higher than those recorded outdoors $(\mathrm{p}<0.05)$, whereas those noted after the AC cleaning fully correspond to their atmospheric levels $(\mathrm{p}>0.05)$. Moreover, the correlation analysis revealed that the mileage of the vehicles did not significantly determine concentration of microorganisms in the air of examined buses $(p>0.05)$. Also the threshold limit values of airborne bacteria and fungi established for public utility facilities (by the Biological Agents' Expert Group at the Polish Interdepartmental Commission for Maximum Admissible Concentrations and Intensities for Agents Harmful to Health in the Working Environment) at the level of $5 \times 10^{3} \mathrm{CFU} / \mathrm{m}^{3}$ for airborne microorganisms were not exceeded at tested buses (6).

\section{Qualitative analysis of bacterial and fungal microbiota in air samples}

Percentage contribution of groups of microorganisms identified in the air of studied buses are showed in Figure 1, whereas all isolated bacterial and fungal species are listed in Table 2. The most prevalent in the air before and after the AC system service were fungi (33-44\% of isolated species) followed by Gram-positive cocci (28-40\%), endospore-forming Gram-positive bacilli (11-35\%), mesophilic actinomycetes (2-7\%) and yeasts $(2-5.5 \%)$. The most frequently isolated bacterial strains belong to Gram-positive cocci from Aerococcus, Staphylococcus, Kocuria and Micrococcus genera as well as endospore-forming Gram-positive bacilli from Bacillus genus. Introduction of cleaning procedures id the $\mathrm{AC}$ systems resulted in lower taxonomical diversity of airborne microbiota.

Staphylococcus, Kocuria and Micrococcus are among the most prevalent commensals or transient organisms of the human microbiome. Hence, their potential emission sources in the studied buses were the passengers, who made their count significantly greater than that of the other bacterial elements of the air microbiota. In turn, among the most prevalent fungi in the air were Penicillium [6] and Aspergillus [8] species. This finding confirmed the observations done by other researchers who found that moulds of the Penicillium, Aspergillus, Acremonium, Alternaria, Cladosporium and Trichoderma genera dominate usually the air of bus cabins $[16,20]$. Human exposure to moulds may be responsible for numerous negative health effects such as such as allergies, rhinitis, bronchial asthma or extrinsic allergic alveolitis and this fact should be taken into account by passengers whose immune system is weakened $[4,8,15]$.

In the air microbiota of studied buses, bacterial pathogens from Streptomyces and Actinomyces genera as well as Aspergillus fumigatus pathogenic fungus were found. Streptomyces

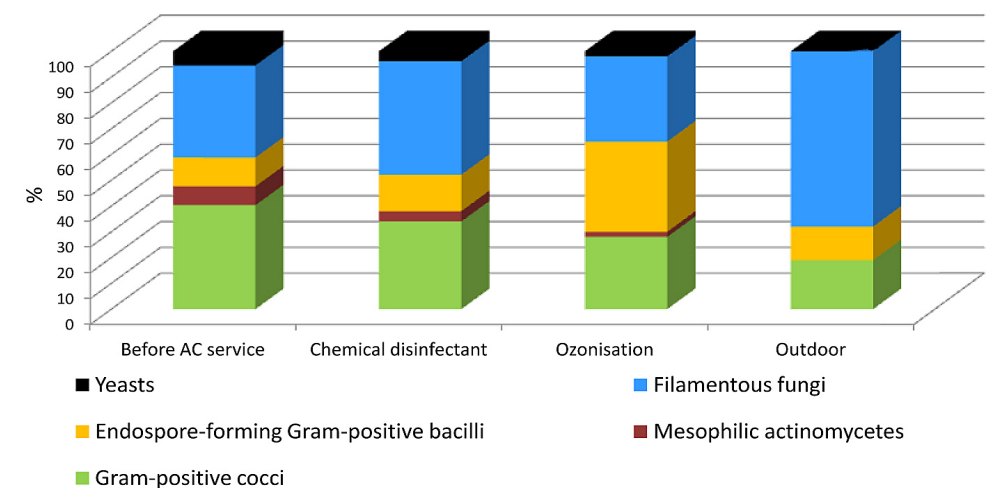

Fig. 1. Percentage contribution of groups of microorganisms in the air of studied municipal buses and in outdoor (atmospheric) air 
Table 2. Bacterial and fungal species identified from the air in municipal buses and from outdoor (atmospheric) air

\begin{tabular}{|c|c|c|c|}
\hline \multirow{2}{*}{ Before AC service } & \multicolumn{2}{|c|}{ After AC service } & \multirow{2}{*}{ Outdoor air } \\
\hline & Chemical disinfectant & Ozonisation & \\
\hline $\begin{array}{l}\text { Gram-positive cocci } \\
\text { Aerococcus spp., Kocuria } \\
\text { spp., Kocuria varians, } \\
\text { Micrococcus spp., } \\
\text { Micrococcus luteus, Rothia } \\
\text { dentocariosa, Staphylococcus } \\
\text { spp., Staphylococcus } \\
\text { haemolyticus, Staphylococcus } \\
\text { epidermidis, Staphylococcus } \\
\text { cohnii, Staphylococcus } \\
\text { hominis, Staphylococcus } \\
\text { sciuri } \\
\text { Endospore-forming Gram- } \\
\text { positive bacilli } \\
\text { Bacillus spp., Bacillus } \\
\text { pumilus, Bacillus cereus, } \\
\text { Bacillus coagulans, Bacillus } \\
\text { licheniformis } \\
\text { Mesophilic actinomycetes } \\
\text { Streptomyces spp. }{ }^{* *} \text {, } \\
\text { Actinomyces spp. }{ }^{* *}\end{array}$ & $\begin{array}{l}\text { Gram-positive cocci } \\
\text { Micrococcus spp., } \\
\text { Micrococcus luteus, } \\
\text { Staphylococcus lentus, } \\
\text { Staphylococcus epidermidis, } \\
\text { Staphylococcus cohnii, } \\
\text { Staphylococcus hominis } \\
\text { Endospore-forming Gram- } \\
\text { positive bacilli } \\
\text { Bacillus cereus, Bacillus } \\
\text { pumilus, Bacillus coagulans, } \\
\text { Bacillus licheniformis }\end{array}$ & $\begin{array}{l}\text { Gram-positive cocci } \\
\text { Micrococcus spp., } \\
\text { Micrococcus luteus, } \\
\text { Staphylococcus lentus, } \\
\text { Staphylococcus epidermidis, } \\
\text { Staphylococcus cohnii, } \\
\text { Staphylococcus hominis } \\
\text { Endospore-forming Gram- } \\
\text { positive bacilli } \\
\text { Bacillus cereus, Bacillus } \\
\text { pumilus, Bacillus coagulans, } \\
\text { Bacillus licheniformis } \\
\text { Mesophilic actinomycetes } \\
\text { Streptomyces spp. }{ }^{* *} \text {, } \\
\text { Actinomyces spp. }{ }^{* *}\end{array}$ & $\begin{array}{l}\text { Gram-positive cocci } \\
\text { Micrococcus spp., } \\
\text { Micrococcus luteus, } \\
\text { Staphylococcus lentus, } \\
\text { Staphylococcus epidermidis, } \\
\text { Staphylococcus cohnii, } \\
\text { Staphylococcus hominis } \\
\text { Endospore-forming Gram- } \\
\text { positive bacilli } \\
\text { Bacillus cereus, Bacillus } \\
\text { pumilus, Bacillus coagulans, } \\
\text { Bacillus licheniformis } \\
\text { Mesophilic actinomycetes } \\
\text { Streptomyces spp. ** }\end{array}$ \\
\hline
\end{tabular}

\begin{tabular}{|c|c|c|c|}
\hline \multirow{2}{*}{ Before AC service } & \multicolumn{2}{|c|}{ After AC service } & \multirow{2}{*}{ Outdoor air } \\
\hline & Chemical disinfectant & Ozonisation & \\
\hline $\begin{array}{l}\text { Filamentous fungi } \\
\text { Acremonium strictum, } \\
\text { Alternaria alternata, } \\
\text { Aspergilllus candidus, } \\
\text { Aspergillus terreus, } \\
\text { Aspergillus fumigatus**, } \\
\text { Aspergillus sydowii, } \\
\text { Aspergillus spp. } \\
\text { *, Chrysosporium } \\
\text { spp., Cladosporium } \\
\text { cladosporioides, } \\
\text { Rhizomucor spp., Penicillium } \\
\text { brevicompactum, Penicillium } \\
\text { chrysogenum, Penicillium } \\
\text { nordicum, Penicillium spp., } \\
\text { Verticillium spp. } \\
\text { Yeasts } \\
\text { Candida guilliermondii, } \\
\text { Rhodotorula mucilaginosa } \\
\end{array}$ & $\begin{array}{l}\text { Filamentous fungi } \\
\text { Alternaria alternata, } \\
\text { Aspergilllus candidus, } \\
\text { Aspergillus terreus, } \\
\text { Aspergillus spp. *, } \\
\text { Chrysosporium spp., } \\
\text { Rhizomucor spp., Penicillium } \\
\text { nordicum, Penicillium spp. }\end{array}$ & $\begin{array}{l}\text { Filamentous fungi } \\
\text { Acremonium strictum, } \\
\text { Aspergilllus candidus, } \\
\text { Aspergillus terreus, } \\
\text { Aspergillus spp. *, } \\
\text { Chrysosporium spp., } \\
\text { Rhizomucor spp., Penicillium } \\
\text { brevicompactum, Penicillium } \\
\text { spp. } \\
\text { Yeasts } \\
\text { Rhodotorula mucilaginosa }\end{array}$ & $\begin{array}{l}\text { Filamentous fungi } \\
\text { Aspergills niger, } \\
\text { Acremonium strictum, } \\
\text { Alternaria alternata, } \\
\text { Aspergillus terreus, } \\
\text { Aspergills niger, Aspergillus } \\
\text { sydowii, Aspergillus } \\
\text { spp. *, Chrysosporium } \\
\text { spp., Cladosporium } \\
\text { cladosporioides, Mucor } \\
\text { plumbeus, Rhizomucor spp., } \\
\text { Penicillium brevicompactum, } \\
\text { Penicillium citrinum, } \\
\text { Penicillium nordicum, } \\
\text { Penicillium spp. }\end{array}$ \\
\hline
\end{tabular}

and Actinomyces are common in the environment, we can find them in soil, decaying organic material, straw, fodder, wastes (compost) and on plant surfaces. Outdoor air is rarely free of their spores, although their numbers in nonagricultural environments are usually small.

Their inhalation can cause severe allergic effects [2, 3, 13]. In turn, numerous allergens isolated from the spores and mycelium of $A s$ pergillus fumigatus may cause infections of the lungs, nose, ocular, cerebral, bone, circulatory system or other organ infections and is the most common aspergillosis factor in humans $[8,15]$. As such, all of them are classified in the group 2 according to their level of risk of infection $[2,13]$.
The size distributions of collected airborne bacteria and fungi are presented in Figure 2. The use of Andersen impactor enabled to divide bioaerosol particles into 6 fractions according to their aerodynamic diameters (i.e. $>7,7-4.7,4.7-3.3,3.3-2.1$, 2.1-1.1 and 1.1-0.65 $\mu \mathrm{m})$. This makes it possible to measure different bioaerosol fractions penetrating particular segments of the human respiratory system. The interaction between aerosol particles and human cells is highly dependent on the site on which they deposition. The particles deposited in the nasopharynx may trigger nasal cavity irritations, the smaller ones - accumulated in the tracheal region - may cause asthmatic reactions, whereas the particles deposited in lower lung segments may induce allergic alveolitis type of reactions $[1,21]$. 

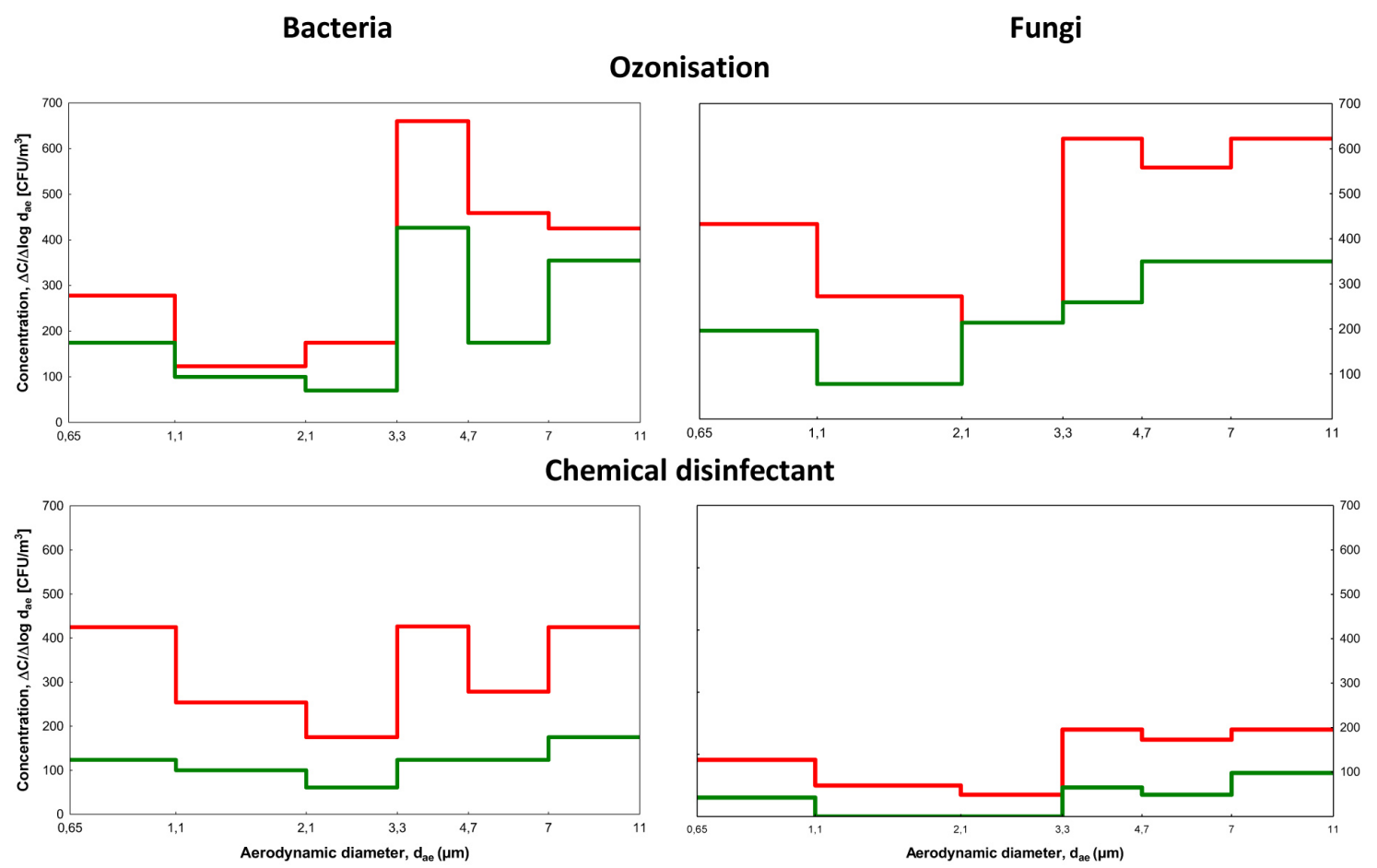

Fig. 2. Size distribution of microbial aerosols in studied municipal buses before (depicted by red line) and after (depicted by green line) AC service

The analysis of size distribution curves before disinfection of air-conditioning system showed that both bacteria and fungi were usually present in the air as single cells or conidia (with aerodynamic diameters of $0.65-1.1 \mu \mathrm{m}$ ) as well as in the form of both fine $(3.3-4.7 \mu \mathrm{m})$ and large $(>7 \mu \mathrm{m})$ microbial and/or microbial-dust aggregates. Introduction of ozonisation or chemical disinfection into the AC system resulted in significant reduction of microbial concentrations in the air of studied buses $(p<0.05)$. Both cleaning methods significantly reduced the presence of single bacterial cells and fungal conidia; however, certain number of (usually large) bacterial (3.3-4.7 $\mu \mathrm{m}$ and $>7 \mu \mathrm{m})$ and fungal $(>7 \mu \mathrm{m})$ aggregates still remained airborne. These results showed that, despite its disinfection, the largest microbial 'load' generated by the AC system may reach the nasal and oral cavities as well as trachea and primary bronchi of the human respiratory system. Such exposure may lead to adverse health outcomes manifesting as nose and eyes' irritations as well as asthmatic and/or allergic alveolitis types of reactions.

\section{CONCLUSIONS}

- Bacterial and fungal aerosol concentrations in the examined municipal buses, measured before and after air-conditioning system service, were low (below $10^{3} \mathrm{CFU} / \mathrm{m}^{3}$ ) and did not exceed the threshold limit values established for airborne microorganisms in public utility facilities.

- Both methods of air-conditioning systems servicing applied in the examined buses (i.e. ozonisation and chemical disinfection with propan2-ol) effectively reduced the concentration of microorganisms in the air inside the vehicles; however, the highest effectiveness was observed when a chemical disinfectant was used.

- Gram-positive cocci of Aerococcus, Staphylococcus, Micrococcus and Kocuria genera, endospore-forming bacilli and filamentous fungi of Penicillium and Aspergillus genera were the common microbal flora in $i$ the studied buses before and after the service of their AC systems.

- Among microorganisms isolated from the air samples collected in examined vehicles were bacteria (Streptomyces spp., Actinomyces spp.) and fungi (Aspergillus fumigatus) classified into the group 2 according to their level of risk of infection, which suggests that users of these vehicles may be exposed to microbial agents harmful to their health.

- In order to eliminate microbiological contamination of the air in municipal buses, the effective disinfection of their air-conditioning systems should be performed at regular basis. 


\section{Acknowledgement}

This paper has been based on the results of a research task carried out within the scope of the fourth stage of the National Programme "Improvement of safety and working conditions" partly supported in 2017-2019-within the scope of state services-by the Ministry of Labour and Social Policy through the grant no. II.G.09. The Central Institute for Labour Protection-National Research Institute is the programme's main coordinator.

\section{REFERENCES}

1. Clauss M. 2015. Particle size distribution of airborne microorganisms in the environmental - a review. Appl Agric Forestry Res 65, 67-100.

2. Directive 2000/54/EC of the European Parliament and of the Council of 18 September 2000 on the protection of workers from risks related to exposure to biological agents at work. Off J Eur Union L 2000; 262/21:21-45.

3. Dutkiewicz J., Górny R.L. 2002. Biologiczne czynniki szkodliwe dla zdrowia - klasyfikacja i kryteria oceny narażenia. Medycyna Pracy, 53, 29-39.

4. Fiegel J., Clarke R., Edwards D.A. 2006. Airborne infectious disease and the suppression of pulmonary bioaerosols. Drug Discovery Today, 11, 51-57.

5. Gołofit-Szymczak M., Stobnicka-Kupiec A., Górny R.L. 2019. Impact of air-condotioning system disinfection on microbial contamination of passenger cars. Air Quality, Atmosphere and Health, DOI: 10.1007/s11869-019-00731-7.

6. Górny R.L., Cyprowski M., ŁawniczekWałczyk A., Gołofit-Szymczak M., Zapór L. 2011. Biohazards in the indoor environment-a role for threshold limit values in exposure assessment. W: Dudzińska M.R. [red.], Management of indoor air quality. CRC Press-Taylor and Francis Group, Londyn.

7. Jo W.K., Lee J.H. 2008. Airborne fungal and bacterial levels associated with the use of automobile air conditioners or heaters, room air conditioners, and humidifiers. Archives of Environmental and Occupational Health, 63(3), 101-107.

8. Jones R., Recer G.M., Hwang S.A., Lin S. 2011. Association between indoor mold and asthma among children in Buffalo, New York. Indoor Air, 21, 156-164.

9. Lee J.H., Jo W.K. 2005. Exposure to airborne fungi and bacteria while commuting in passenger cars and public buses. Atmospheric Environment, 39, 7342-7350.
10. Li J.L., Mingzhen S., Fangxia Z.Z., Yao M., Wu C.Y. 2013. Characterization of biological aerosol exposure risks from automobile air conditioning system. Environmental Science and Technology, 47, 10660-10666.

11. Luksamijarulkul P., Sundhiyodhin V., Luksamijarulkul S., Kaewboonchoo O. 2004. Microbial air quality in mass transport buses and work-related illness among bus drivers of Bangkok Mass Transit Authority. Journal of the Medical Association of Thailand, 87, 697-703.

12. Nowakowicz-Dębek B., Pawlak H., Wlazło Ł., Maksym P., Kapica J., Chmielowiec-Korzeniowska A., Trawińska B. 2017. Evaluating bioaerosol exposure among bus drivers in the public transport sector. Journal of Occupational and Environmental Hygiene, 14(11), D169-D172.

13. Ordinance of the Minister of Health of April 22, 2005, on hazardous biological agents in the work environment and the protection of health of workers occupationally exposed to them. Journal of Laws, 81, 716.

14. Ross M., Curtis L., Scheffn P., Hryhorczuk D., Ramakrishnan V., Wadden R., Persky V. 2000. Association of asthma symptoms and severity with indoor bioaerosols. Allergy, 55(8), 705-711.

15. Rylander R., Fogelmark B., Ewaldsson B. 2008. Moldy environments and toxic pneumonitis. Toxicology and Industrial Health, 24, 177-180.

16. Sowiak M., Kozajda A., Jeżak K., SzadkowkaStańczyk I. 2018. Does the air condition system in busses spread allergic fungi into driver space? Environmental Science and Pollution Research, 25, 5013-5023.

17. Sturm R. 2012. Modeling the deposition of bioaerosols with variable size and shape in the human respiratory tract: a review. Journal of Advanced Research, 3(4), 295-304.

18. Sykes P., Jones K., Wildsmith J.D. 2007. Managing the potential public health risks from bioaerosol liberation at commercial composting sites in the UK: An analysis of the evidence base. Resources, Conservation and Recycling, 52, 410-424.

19. Udaya Prakash N.K., Bhuvaneswari S., Ranjith Kumar M., Lankesh S., Rupesh K. 2014. A study on the prevalence of indoor mycoflora in air conditioned buses. British Microbiology Research Journal, 4(3), 282-292.

20. Wang Y. 2011. Seasonal difference of airborne bacteria and fungi in commuter busses. Environmental Engineering Science, 28(6), 461-467.

21. Wang Y.F., Tsai C.H., Huang Y.T., Chao H.R., Tsou T.C., Kuo Y.M., Wang L.C., Chen S.H. 2013. Size distribution of airborne fungi in vehicles under various driving conditions. Archives of Environmental and Occupational Health, 68, 95-100. 